\title{
NEOLIBERALISM, ECONOMIC GLOBALIZATION AND THE NEW INTERNATIONAL DIVISION OF LABOR
}

\author{
Irena Andreeska ${ }^{260}$
}

https://doi.org/10.31410/itema.2018.690

\begin{abstract}
The new international division of labor is based on the globalization of the production, whose creators are the multinational companies that gradually became main factors of the new world economy.

Even with not similar intensity and in accordance with the different positions that the countries have inside the world system, the transformations were intertwined in the whole system. Their implications regarding to the national economic politics can concisely illustrate through the following insistences and requests: national economies have to open towards the world market; an advantage should be given to the export economy; the efforts of the monetary and fiscal policy should be directed towards decreased inflation and national debt, and maintenance of the balance between the import and the export prices; the rights of the private owners should be clearly defined and invulnerable; the entrepreneurship state sector should be privatized etc. One of the most noticeable transformations that happened under the influence of the neo-liberal economic globalization is the huge concentration of the economic power in the hands of the transnational companies. The economic globalization is supported by the neo-liberal economic consensus, that is consisted of three institutional news: drastic limitation of the state regulation to the economics, new rules for the international ownership of the foreign investors, innovators and innovation creators that could become intellectual ownership and subordination of the national states to the multilateral agencies such as the World Bank, the International Monetary Fund (IMF) and the World Trade Organization.

The respect of the neoliberal regulations is mostly imposed of the peripheral countries. Even the countries that make the nucleus of the world system, and those whose public debt increases, have consequences from the decisions of the agencies for the financial rating.

The computer technology is possible technology that similar to the conductor's stick conducts from the center in terms of the economic and political power. According to the terminology of globalization, the industrial activity has been described as an efficient substitution of the workers with the machines, and the competition is higher if the workers' wages are decreased.
\end{abstract}

Keywords: globalization, neoliberalisam, labor, neoliberal economic consensus

\section{Technology and the new division of labor}

$\mathrm{T}$ he great reversal in globalization of the world economy, which marks the new technological era - happened in the 19th century. Some believe that exactly this era of technology has led to the key changes in the quality of life. It should not be forgotten that the production grew rapidly, and international trade developed more rapidly under the conditions of a stable monetary system, which was guaranteed by the later deflated gold standard.

\footnotetext{
${ }^{260}$ PVPU Euro College Kumanovo, Macedonia
} 
The existing forces continue to speak about every new generation of technological discovery, with the same utopian terminology that describes every previous generation, starting from motor vehicles, flying, electricity, steam drive and clean nuclear energy, which are presented to change from which the breath stops. Today are common is the world's computer networks, which are said to be able to strengthen the community and the individual, while the truth is completely different. The global computer-satellite connection, besides offering fantastic and new weapons for financial speculation, increases the capacity of global corporations, their global enterprise of a few thousands of workers armed with computers to be internally uninterrupted connected, so that momentary changes are achieved with one unique touch of keyboard. Computer technology is most likely a technology that is similar to the conductor steak that dirigues from the center, at least in terms of economic and political power. One thing is crystal clear: today's global industry cannot exist without computers. The technology makes globalization possible in a way that allows an invisible degree of control.

The scientific-technological revolution does not terminologically reflect the far-reaching, the scale and complexity of the changes today and changes in perspective, since it speaks of mutational changes only in science and technology, and in reality works for the world historical fracture, in whose vortex our entire planet is entangled, for the occurrence of the "global village", for the creation of means of communication that make it possible to access all points of the globe in a minute. In this scientific-technological revolution there are epochal changes in a dialectic unity, which are along with all spheres of life and work of the people, and are dictating by the changes in science and technology. Everything is in movement, everything is twisted, the present is shrouded in the past, and the future becomes a reality.

In the meantime, the new types of technology such as biotechnology and genetic engineering set the development framework of a completely new field, enabling the computerization of our genetic potential, the very heart of life. The discovery and creation of new forms of life, from a cell, through insects and animals, to man, leaves deep moral and ethical consequences in the field of agro-culture in third world countries, in ecology and human rights.

Globalization transforms conglomerates and multinational companies into centers of global power, decisive political factors and global awareness creators. According to the terminology of globalization, the industrial activity is described as an efficient replacement of the workers with machines, and the competitiveness is higher if the wages of workers are lowered, in order to dress in the direction of the foreign competitors.

The transfer of technology is not limited to the production of goods but also in the field of services (banking, trade and catering).

Such a division and, in general, such a definition of technology can be noted that it is too tight. The technology is not only produced in factories and enterprises, but in institutes and universities, in public and private laboratories, etc., and in many cases individually (silent, noncodified knowledge). Therefore, it is also transferred with the education of such institutions and the acquisition by those individuals. In general, technology is also in the form of books, articles and reports. Less tangible it is getting with the participation in the scientific and expert gatherings, symposia, etc. with "brain drain" and so on. "Hunting" talents through special bureaus and later the accent is on a particularly specific and well-known phenomenon: the underdeveloped countries "supply" the developed countries with "gray matrix", and for that they do not receive compensation and the "grey matrix" is so necessary in the country from which it is fading. 
The commercial transfer of technology takes place mainly in nine forms: foreign direct investments, licensing, franchises, management agreements, marketing agreements, service agreements, turnkey agreements and international subcontracting.

\section{Conclusion}

Will the "story" of globalization and technology development be completed like any other "great story" or will it become endless? On this question, some hypotheses can be posed. One of them might be the following:

-As an ideological and theoretical "mega-story" it will experience the fate of the other "stories" that at one time gathered the prevailing spirit of time. Nevertheless, as the living, developmental, best-described world-historical "story" - it is objectively endless.

The most important question about the processes of current technology is: are these processes in the long run acting in the direction of making better international division of labor and destroying poverty and inequality in living conditions between people or in changed forms it leads to an extended reproduction of poverty and inequality?

It is certain that a world-wide strategy deepens the gap between the rich and the poor, increases unemployment and in many cases it spreads absolute poverty - to many countries and nations, and to the world as a whole, bring them an economy of disaster and a growing danger.

The compensation between the new technology and the workers is the most remarkable product of globalization.

From the previous one we can synthesize the following:

In spite of scientific and technological achievements, approximately one billion people in the world live on the "edge of existence". For many in developing countries, the development of technology has not brought the promised benefits. Even countries that have benefited from globalization have many poor and unemployed people, and in many countries the difference between the rich and the poor has increased.

In underdeveloped countries and around the world too many workers are neglected, in trade, finance, technology, exactly in those areas that can help them in the development and reduction of poverty.

Country-level policies are the key to reducing poverty, even in times of globalization.

It is reasonably considered that the allocation of money and the financing of poor countries is a simple but unsuccessful method. Money is transferred through countless non-governmental and governmental organizations and with each diversion they melt into someone's pocket or are extremely inadequately invested. Problems thus remain because they are not resolved by people directly affected by these problems, but by people to whom those problems are rather distant.

\section{Bibliography}

1. Andreeska I. (2010) doctoral dissertation

2. Stiglitz E. Dzozef, (2002) Globalization and it's discontents, w.w. norton \& company, New York

3. G. Kolodko, Globalization and development prospectives of postsocialistic countries, Economic institute, MAGOR, Skopje, 2004 
4. www.socialwatchreport.com

5. I. Goldin, K. Reinert, Globalization for development, a publication of the World bank and Palgrave Macmilian, April, 2007

6. Z. Vidojevic, Kuda vodi globalizacija, IP "Filip Visnic, Institut drustvenih nauka, Beograd, 2005

7. Gary Burtless et al. Global phobia: Confronting fears about Open trade, Brookings Institution, Progressive Policy Institute, and Twentieth Century Fund, 2010. 